\title{
Processing of chromogranin A by plasmin provides a novel mechanism for regulating catecholamine secretion
}

\author{
Robert J. Parmer, ${ }^{1}$ Manjula Mahata, ${ }^{1}$ Yun Gong, ${ }^{2}$ Sushil K. Mahata,,${ }^{1}$ Qijiao Jiang, ${ }^{1}$ \\ Daniel T. O'Connor, ${ }^{1}$ Xiao-Ping Xi, ${ }^{1}$ and Lindsey A. Miles ${ }^{2}$ \\ ${ }^{1}$ Department of Medicine, University of California, and Veterans Administration Medical Center, San Diego, California, USA
${ }^{2}$ Department of Vascular Biology, The Scripps Research Institute, La Jolla, California, USA
}

Address correspondence to: Robert J. Parmer, Nephrology/Hypertension (9111-H), University of California,

San Diego, 3350 La Jolla Village Drive, San Diego, California 92161, USA.

Phone: (858) 552-8585 ext. 7356; Fax: (858) 552-7549; E-mail: rparmer@ucsd.edu.

Received for publication May 21, 1999, and accepted in revised form August 28, 2000.

\begin{abstract}
Chromogranin $\mathrm{A}(\mathrm{CgA})$ is the major soluble protein in the core of catecholamine-storage vesicles and is also distributed widely in secretory vesicles throughout the neuroendocrine system. CgA contains the sequences for peptides that modulate catecholamine release, but the proteases responsible for the release of these bioactive peptides from CgA have not been established. We show here that the major fibrinolytic enzyme, plasmin, can cleave $\mathrm{CgA}$ to form a series of large fragments as well as small trichloroacetic acid-soluble peptides. Peptides generated by plasmin-mediated cleavage of CgA significantly inhibited nicotinic cholinergic stimulation of catecholamine release from PC12 cells and primary bovine adrenal chromaffin cells. We also show that the zymogen, plasminogen, as well as tissue plasminogen activator bind saturably and with high capacity to catecholaminergic (PC12) cells. Occupancy of cell surface binding sites promoted the cleavage of CgA by plasmin. Positive and negative modulation of the local cellular fibrinolytic system resulted in substantial alterations in catecholamine release. These results suggest that catecholaminergic cells express binding sites that localize fibrinolytic molecules on their surfaces to promote plasminogen activation and proteolytic processing of $\mathrm{CgA}$ in the environment into which $\mathrm{CgA}$ is secreted to generate peptides which may regulate neuroendocrine secretion. Interactions between $\mathrm{CgA}$ and plasmin(ogen) define a previously unrecognized autocrine/paracrine system that may have a dramatic impact upon catecholamine secretion.
\end{abstract}

J. Clin. Invest. 106:907-915 (2000).

\section{Introduction}

The mechanisms and specific proteases involved in the processing of prohormone precursors in the neuroendocrine system are not fully established. Chromogranin $\mathrm{A}(\mathrm{CgA})$ is the major soluble protein in the core of catecholamine-storage vesicles and is released with catecholamines by exocytosis from the chromaffin cells of the adrenal medulla and from sympathetic axons. $\mathrm{CgA}$ is found in secretory vesicles throughout the neuroendocrine system and may exemplify a prototypical prohormone precursor (1). Recent evidence suggests that $\mathrm{CgA}$ is a precursor of several peptides that affect cellular secretory function. These peptides include pancreastatin (porcine $\mathrm{CgA}_{240-288}$, first isolated from porcine pancreas; ref. 2), which inhibits glucose-stimulated insulin release and parathyroid hormone release from islet beta-cells and chief cells, respectively; vasostatin (human $\mathrm{CgA}_{1-76}$; refs. 3 , 4) or $\beta$-granin (rat $\mathrm{CgA}_{1-114}$; refs. 5-7), which inhibits parathyroid hormone release and relaxes vascular smooth muscle; and parastatin (porcine $\mathrm{CgA}_{347-419}$; ref. 8), which inhibits parathyroid hormone release. In addition, recent studies have revealed that $\mathrm{CgA}$ may function as a prohormone from which peptides are released that modulate the function of catecholaminergic cells. Trypsin digestion of CgA produces peptides that inhibit release of catecholamines from adrenal medullary cells in culture (9).

Previous studies have demonstrated that CgA processing occurs in a specific tissue-dependent fashion with the extent and pattern of processing varying widely from one neuroendocrine site to the next (10). CgA processing may take place intracellularly as well as extracellularly, that is, after secretion into the extracellular space $(9,11,12)$. Indeed, previous studies have shown that extracellular processing appears to be particularly important for generation of catecholaminerelease inhibitory activity from the parent $\mathrm{CgA}$ molecule in the vicinity of the chromaffin cell $(9,11)$. Although a number of studies have examined the role of prohormone convertases (13-15) that process prohormone precursors intracellularly to generate regulatory peptides, few studies have focused on the role of other proteases and mechanisms of extracellular processing in the generation of bioactive peptides.

Recent studies have demonstrated that catecholamine release-inhibitory activity is generated when CgA is co-incubated with chromaffin cells, suggesting that at least some component of the cleavage occurs 
extracellularly (as would occur after secretion) (9, 11, 12, 16). Thus, the secretion of CgA, followed by its appropriate proteolytic processing, may exert an autocrine/paracrine negative-feedback control on local catecholamine release. However, the protease(s) responsible for generating this activity in the chromaffin cell environment have not been identified (17). The only proteases shown to generate catecholamine releaseinhibitory activity from $\mathrm{CgA}$ are the bacterial endoproteinase Lys C (16) and trypsin (9), proteases that are not present in the extracellular environment of the chromaffin cell. Because plasmin has a substrate-recognition specificity similar to that of trypsin and endoproteinase Lys C (18), and its zymogen, plasminogen, circulates at a high concentration $(2 \mu \mathrm{M})(19)$ and is present in the extracellular environment of the chromaffin cell, we examined whether plasmin might participate in the processing of CgA.

Early work in the 1950s suggested a role for the plasminogen/plasmin system in the processing and degradation of bioactive peptides, including ACTH, growth hormone, and glucagon (20). Furthermore, we found recently that the major activator of plasminogen, tissue plasminogen activator ( $t-P A)$, is expressed in chromaffin cells, is sorted into the regulated pathway of secretion (into catecholamine storage vesicles), and is coreleased with catecholamines and other secretory vesicle protein constituents including CgA, by chromaffin cell stimulation $(21,22)$. Plasminogen activators are present in a variety of other neuronal and endocrine tissues, further suggesting that components of the fibrinolytic system might participate in neuroendocrine prohormone processing (23).

Plasminogen activation and plasmin function are promoted by colocalization of plasminogen and plasminogen activators on cell surfaces (reviewed in ref. 24). Plasmin can remain associated with its receptors where it is relatively protected from its major inhibitor, $\alpha_{2}$ antiplasmin $(25,26)$. Thus, plasminogen receptors function to localize the proteolytic activity of plasmin in the local milieu of cells, an environment into which prohormones are secreted directly. However, the fundamental importance of cell-surface receptors for plasminogen in regulating prohormone processing has not been investigated previously. High-affinity t-PA-binding sites have been described on PC12 pheochromocytoma cells (27). Therefore, we tested whether these cells also could bind the substrate plasminogen to promote prohormone processing.

Our results demonstrate that (a) plasmin processes the major neurosecretory protein of these cells, CgA, to liberate bioactive fragments that inhibit secretagogue-stimulated catecholamine release; (b) plasminogen binds specifically to both high-affinity $\left(\mathrm{K}_{\mathrm{d}}=77 \mathrm{nM}\right)$ and loweraffinity $\left(\mathrm{K}_{\mathrm{d}}=8.87 \mu \mathrm{M}\right)$ binding sites on PC12 cells; (c) binding of plasminogen to its cellular binding sites promotes the processing of $\mathrm{CgA}$; and (d) perturbation of the local cellular plasminogen/t-PA system results in substantial alterations in catecholamine secretion. These interactions between CgA and plasmin(ogen) represent a heretofore unrecognized relationship between catecholaminergic and fibrinolytic pathways and a novel autocrine/paracrine system that may have a dramatic impact upon catecholamine secretion.

\section{Methods}

Proteins. Human Glu-plasminogen, the native circulating form of the molecule, was isolated from fresh human blood collected into $3 \mathrm{mM}$ benzamidine, $3 \mathrm{mM}$ EDTA, 100 U/ml Trasylol (Miles Laboratories, Kankakee, Illinois, USA), and $100 \mu \mathrm{g} / \mathrm{ml}$ soybean trypsin inhibitor (Sigma, St. Louis, Missouri, USA). The plasma was subjected to affinity chromatography on lysine-Sepharose (28) in PBS (0.01 M sodium phosphate, pH 7.3, $0.15 \mathrm{M}$ $\mathrm{NaCl}$ ) with $1 \mathrm{mM}$ benzamidine, $0.02 \% \mathrm{NaN}_{3}$, and $3 \mathrm{mM}$ EDTA, followed by molecular exclusion chromatography on Ultrogel AcA44 (IBF Biotechnics, Villeneuve-laGarennem, France). The plasminogen concentration was determined spectrophotometrically at $280 \mathrm{nM}$ using an extinction coefficient of 16.8 (29). Human CgA was purified from human pheochromocytoma chromaffin vesicle lysates as described (30). The following proteins were obtained from commercial sources: single-chain recombinant human t-PA (Genentech Inc., South San Francisco, California, USA); urokinase (u-PA) and lysozyme (Calbiochem-Novabiochem, San Diego, California, USA), streptokinase and ovalbumin (Sigma); $\alpha_{2}-$ antiplasmin (Athens Research and Technology Inc., Athens, Georgia, USA); and ribonuclease (Worthington Biochemical Corp., Freehold, New Jersey, USA).

Glu-plasminogen and CgA were iodinated using a modified chloramine $\mathrm{T}$ procedure as described elsewhere (31), and the radiolabeled proteins were analyzed on SDS-PAGE. Diisopropyl fluorophosphate (DFP) was used to inactivate t-PA, which was iodinated using the lactoperoxidase method, as described elsewhere (32).

The activity of plasmin was measured spectrophotometrically using the chromogenic substrate, D-Val-LeuLys-paranitroanilide (S2251; Kabi, Stockholm, Sweden) and compared with a standard titrated with a plasmin standard (Kabi). An anticatalytic antiplasminogen $\mathrm{mAb}$ was produced by immunization of mice with plasminogen. The $\mathrm{Ab}$ recognized the plasminogen kringle 5-protease domain and inhibited plasmin activity as detected with the tripeptide substrate, D-Val-LeuLys-paranitroanilide.

Cells. Rat pheochromocytoma PC12 cells (33) were obtained from David Schubert (Salk Institute, San Diego, California, USA) and were grown as described $(21,34)$ at $37^{\circ} \mathrm{C}, 6 \% \mathrm{CO}_{2}$, in $10-\mathrm{cm}$ plates in DMEM supplemented with 5\% FCS, 10\% horse serum, $100 \mathrm{U} / \mathrm{ml}$ penicillin $\mathrm{G}$, and $100 \mu \mathrm{g} / \mathrm{ml}$ streptomycin. We obtained the PC12 cell line \#CS1F9 (from Randall Pittman, University of Pennsylvania, Philadelphia, Pennsylvania, USA) (35), which overexpresses t-PA. These cells were developed by stable transfection with the expression vector pCMV-t-PA (35), containing the full-length $(2.6 \mathrm{~kb}) \mathrm{cDNA}$ for rat t-PA, under the control of the cytomegalovirus promoter and 


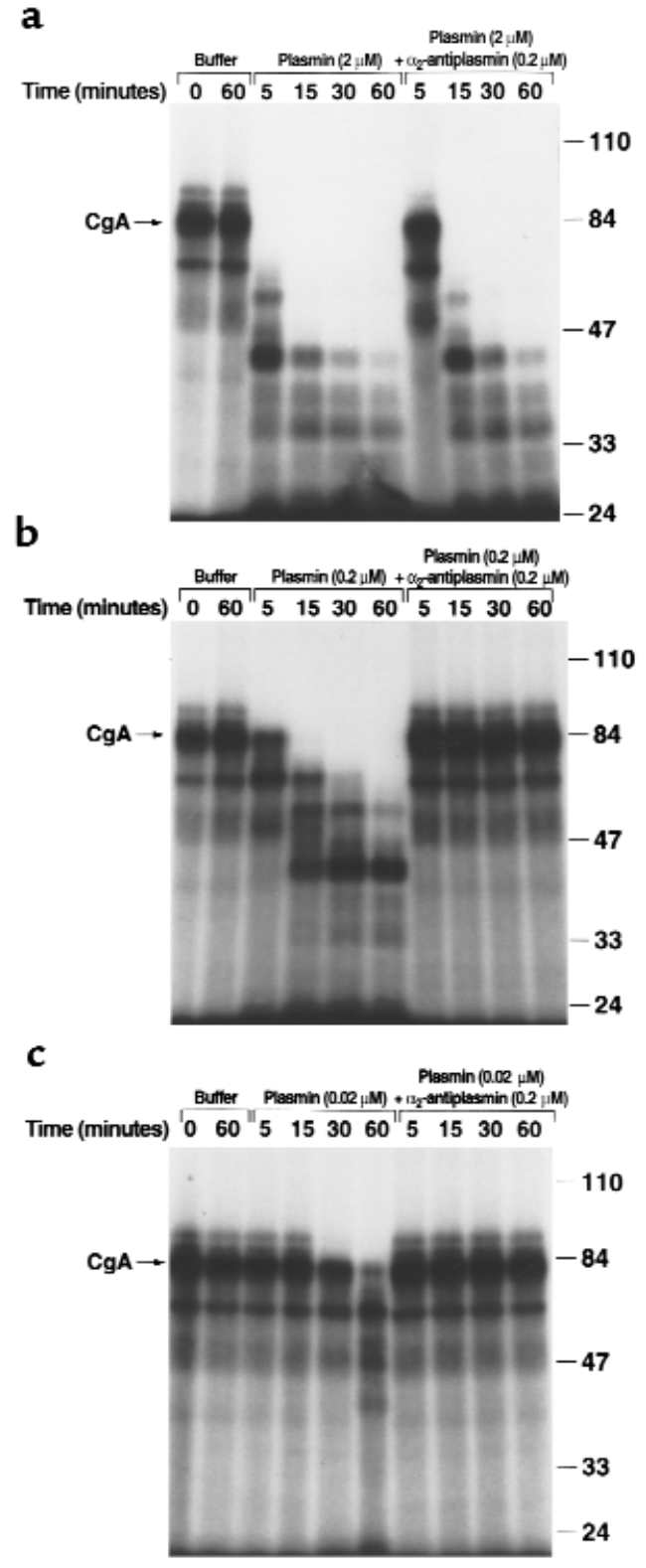

Figure 1

Cleavage of CgA by plasmin. Human ${ }^{125} \mathrm{I}-\mathrm{CgA}(1.5 \mathrm{nM})$ was incubated with either buffer (PBS) or streptokinase $(100 \mathrm{U} / \mathrm{ml})$ plus $2 \mu \mathrm{M}$ plasminogen (a), $0.2 \mu \mathrm{M}$ plasminogen (b), or $0.02 \mu \mathrm{M}$ plasminogen (c) in $0.01 \mathrm{M}$ Tris $\mathrm{Cl}, \mathrm{pH} 8.0,0.15 \mathrm{M} \mathrm{NaCl}$, at $37^{\circ} \mathrm{C}$ for the indicated times in the presence or absence of $0.2 \mu \mathrm{M} \alpha_{2}$-antiplasmin. The generation of active plasmin was verified spectrophotometrically as cleavage of the chromogenic substrate, S-2251, D-Val-Leu-Lys-paranitroanilide. Samples were electrophoresed on 8\% SDS-PAGE under nonreducing conditions. $M_{r}$ size standards (in thousands) are indicated on the right. In controls, neither plasminogen alone nor streptokinase alone cleaved the parent CgA molecule (data not shown).

the neomycin-selectable marker. These cells have been characterized extensively using t-PA-specific ELISA, immunoblotting, protease assays, Northern and Southern blotting, and exhibit approximately fivefold greater tPA expression than control-transfected (pCMV vector only, without t-PA insert) cells (35).
Bovine chromaffin cells were isolated from bovine adrenal glands as described (36). The cells were cultured in MEM containing 1\% nonessential amino acids, $1 \%$ L-glutamine, $10 \%$ FCS, $1 \%$ amphotericin B, 100 $\mathrm{U} / \mathrm{ml}$ penicillin, and $100 \mu \mathrm{g} / \mathrm{ml}$ streptomycin for 3-5 days before the assay.

Ligand-binding assays. Binding assays with PC12 cells were performed with the cells in suspension $(0.5-1.0 \times$ $10^{7}$ cells $/ \mathrm{ml}$ ) in HBSS containing $0.1 \%$ BSA in a final volume of $200 \mu \mathrm{l}$ in $1.5-\mathrm{ml}$ polypropylene tubes containing cells and radiolabeled plasminogen or radiolabeled t-PA. Bound ligand was separated from free ligand by layering three, $50-\mu \mathrm{l}$ aliquots from each reaction mixture over $300 \mu \mathrm{l}$ of $20 \%$ sucrose in $500-\mu \mathrm{l}$ polypropylene centrifuge tubes, centrifuging for $2 \mathrm{~min}$ utes in a microfuge, and amputating the tube tips. This process resulted in recovery of $95 \%$ of the cells in the tube tips, based on protein determinations. Precipitation of radiolabeled plasminogen or t-PA in the absence of cells was negligible $\left(0.06 \%\right.$ of added ${ }^{125}$ I-ligand).

Proteolytic cleavage of CgA by plasmin. Human ${ }^{125} \mathrm{I}-\mathrm{CgA}$ $(1.5 \mathrm{nM})$ was incubated with either buffer $(0.01 \mathrm{M}$ Tris $\mathrm{Cl}, \mathrm{pH}$ 8.0., $0.15 \mathrm{M} \mathrm{NaCl})$ or streptokinase $(100 \mathrm{U} / \mathrm{ml})$, plus varying concentrations of plasminogen, or PBS at $37^{\circ} \mathrm{C}$ for $0,5,15,30$, or 60 minutes in the presence or absence of $0.2 \mu \mathrm{M} \alpha_{2}$-antiplasmin. Samples were analyzed by SDS-PAGE on $8 \%$ gels (37) under nonreducing conditions. The gels were dried and exposed at $-80^{\circ} \mathrm{C}$ to Kodak X-OMAT AR film (Eastman Kodak Co., Rochester, New York, USA) for 12 hours with an image-intensifying screen. Cleavage of ${ }^{125} \mathrm{I}-\mathrm{CgA}$ into fragments of molecular weight $\left(\mathrm{M}_{\mathrm{r}}\right)$ less than 6,000 was assessed by precipitation of samples in 13\% trichloroacetic acid (TCA), according to the method we have used previously (31).

Secretagogue-stimulated catecholamine secretion. PC12 cell and primary bovine adrenal chromaffin cell-secretion studies were performed as described previously $(21,34)$. Briefly, cells were labeled for 2 hours with $\left[{ }^{3} \mathrm{H}\right]$-norepinephrine at $1 \mu \mathrm{Ci} / \mathrm{ml}$ in cell culture medium, washed twice with release buffer $(150 \mathrm{mM} \mathrm{NaCl}, 5 \mathrm{mM} \mathrm{KCl}, 2$ $\mathrm{mM} \mathrm{CaCl}_{2}, 10 \mathrm{mM}$ HEPES, pH 7.0), and incubated at $37^{\circ} \mathrm{C}$ for 30 minutes in release buffer with or without nicotine. After aspirating the release buffer, cells were harvested and lysed in release buffer containing $0.1 \%$ Triton X-100. $\left[{ }^{3} \mathrm{H}\right]$-norepinephrine in the release buffer and cell lysates was determined by liquid-scintillation counting, and results were expressed as percentage of secreted: amount in release buffer/total (amount in release buffer + amount in cell lysate).

Statistics. Results of secretion experiments are expressed as mean plus or minus SEM. Results were analyzed by ANOVA followed by Student-NewmanKeuls post hoc tests for multiple comparisons.

\section{Results}

Cleavage of CgA by plasmin. We examined whether CgA could be processed by plasmin. ${ }^{125} \mathrm{I}-\mathrm{CgA}(1.5 \mathrm{nM})$ was incubated with increasing concentrations of human 


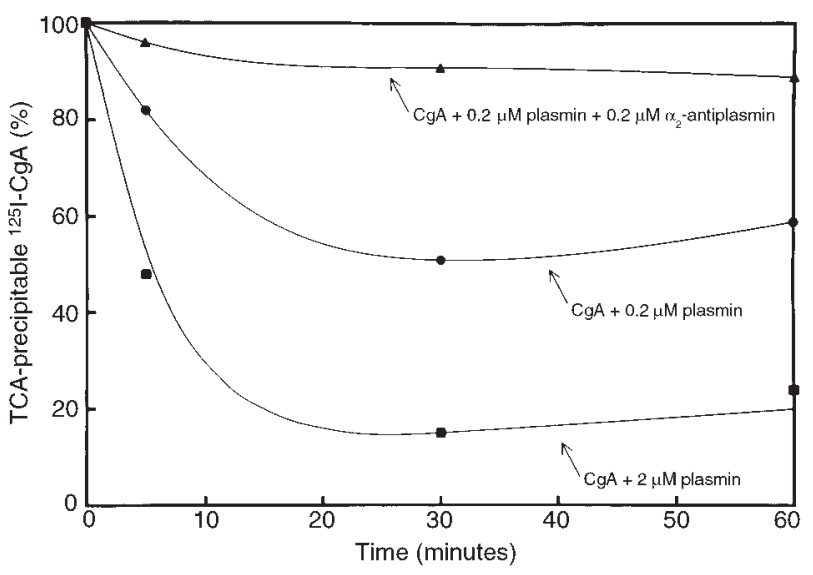

Figure 2

Cleavage of CgA by plasmin: TCA precipitability. Human ${ }^{125} \mathrm{I}-\mathrm{CgA}$ was incubated with either buffer (shown as $100 \%$ TCA precipitability) or streptokinase $(100 \mathrm{U} / \mathrm{ml}$ ) plus $2 \mu \mathrm{M}$ plasminogen (closed squares), $0.2 \mu \mathrm{M}$ plasminogen (closed circles), or $0.2 \mu \mathrm{M}$ plasminogen plus $0.2 \mu \mathrm{M} \alpha_{2}$-antiplasmin (closed triangles). Solubility in $13 \%$ TCA was determined at the indicated time points and subtracted from $100 \%$ to give percentage of TCA-precipitable counts.

plasmin. The extent of cleavage of the CgA molecule was analyzed by SDS-PAGE (Figure 1, a-c). Using three different concentrations of plasmin, ${ }^{125} \mathrm{I}-\mathrm{CgA}$ was cleaved, and the extent of cleavage was dependent upon both the plasmin concentration and the time of incubation. Major products were sequentially produced at apparent molecular weights ( $\left.\mathrm{M}_{\mathrm{r} \text { app's }}\right)$ of $65 \mathrm{~K}, 55 \mathrm{~K}, 43 \mathrm{~K}$, $38 \mathrm{~K}, 34 \mathrm{~K}$, and $29 \mathrm{~K}$.

To verify that the cleavage was specific for plasmin, the incubations were also performed in the presence of the major inhibitor of plasmin, $\alpha_{2}$-antiplasmin. In the presence of an equimolar ratio of $\alpha_{2}$-antiplasmin to plasmin (Figure 1b), or a tenfold molar excess of $\alpha_{2}$ antiplasmin over plasmin (Figure 1c), no cleavage of ${ }^{125} \mathrm{I}-\mathrm{CgA}$ was observed. When plasmin was present at a tenfold molar excess over $\alpha_{2}$-antiplasmin, the rate of cleavage of the ${ }^{125} \mathrm{I}-\mathrm{CgA}$ was decreased (Figure 1a). The cleavage was specific; other fibrinolytic proteins, t-PA $(0.8 \mu \mathrm{M})$ and $\mathrm{u}-\mathrm{PA}(500 \mathrm{nM})$ did not cleave ${ }^{125} \mathrm{I}-\mathrm{CgA}$.

To assess whether plasmin also might produce ${ }^{125} \mathrm{I}$ CgA proteolytic products that were too small to be included within the polyacrylamide gels, ${ }^{125} \mathrm{I}-\mathrm{CgA}$ was incubated with plasmin and the integrity of the ${ }^{125} \mathrm{I}-\mathrm{CgA}$ tested using the criterion of precipitability in 13\% TCA. Plasmin treatment decreased the TCA precipitability of the ${ }^{125} \mathrm{I}-\mathrm{CgA}$ in a dose- and time-dependent fashion (Figure 2). The detection of TCA-soluble radioactivity suggested that $\mathrm{CgA}$ fragments of $\mathrm{M}_{\mathrm{r}}$ less than 6,000 had been produced during the plasmic digestion. When $\alpha_{2}$ antiplasmin was present at the same molar concentration as plasmin, TCA precipitability was not affected. Thus, the formation of the smaller molecular-weight fragments was similarly due to the presence of plasmin.

Effect of plasmin treatment of CgA on catecholamine release. We next tested whether the peptide fragments generated by plasmic cleavage of CgA could inhibit secreta- gogue-stimulated catecholamine release from catecholaminergic cells. PC12 cells or primary bovine adrenal chromaffin cells were preloaded with $\left[{ }^{3} \mathrm{H}\right]$ norepinephrine. The cells were then stimulated with the chromaffin cell secretagogue, $60 \mu \mathrm{M}$ nicotine (which acts through nicotinic cholinergic receptors), in the presence or absence of $1 \mu \mathrm{M}$ human CgA that had been digested (at $37^{\circ} \mathrm{C}$ for 60 minutes) by $2 \mu \mathrm{M}$ plasmin, followed by inactivation of the plasmin with $1000 \mathrm{U} / \mathrm{ml}$ Trasylol. Digestion of CgA with plasmin resulted in liberation of bioactive peptides that suppressed catecholamine secretion $(P<0.001)$. The extent of inhibition by plasmin-generated $\mathrm{CgA}$ fragments was approximately $45-50 \%$ in PC12 cells and even greater, approximately $70-75 \%$, in bovine chromaffin cells (Figure 3). These results suggest that plasmin cleavage of $\mathrm{CgA}$ generates peptides that suppress secretagogue-stimulated catecholamine release from these cells. Secretion in the presence of undigested CgA caused a more modest decrease in nicotine-mediated catecholamine release $(14 \%$ in PC12 cells and $36 \%$ in bovine chromaffin cells; $P<0.01$ ), consistent with the presence of an endogenous chromaffin cell protease system capable of cleaving CgA into bioactive peptides $(9,11,12,16)$. In control experiments, plasmin plus Trasylol without CgA had no effect on nicotine-mediated catecholamine secretion.

Interaction of fibrinolytic components with PC12 cells. The ability of plasminogen to interact with neurosecretory cells was assessed using PC12 cells. ${ }^{125}$ I-plasminogen

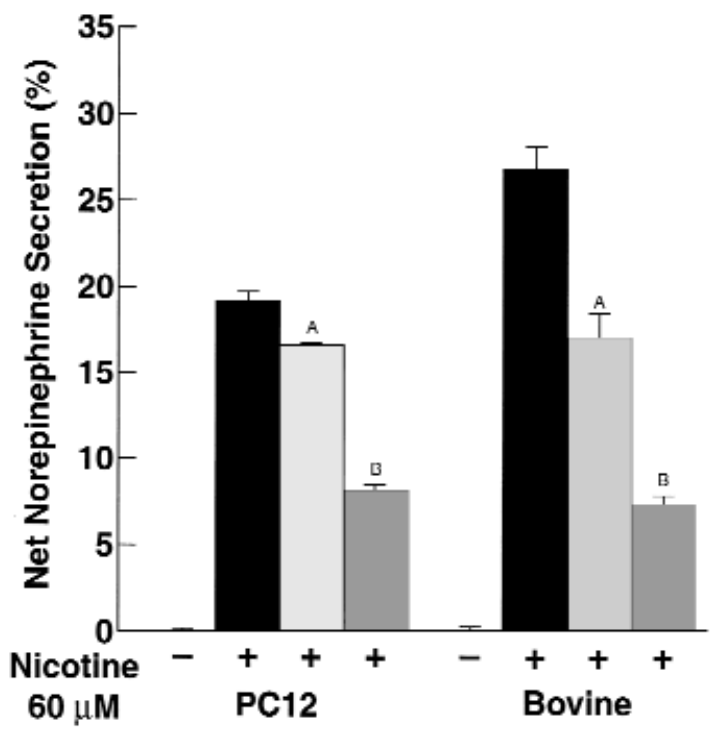

Figure 3

Suppression of catecholamine release by plasmin-generated $\mathrm{CgA}$ fragments. PC12 cells or primary bovine adrenal cells were stimulated with $60 \mu \mathrm{M}$ nicotine in the absence (solid bars) or presence of $1 \mu \mathrm{M}$ human $\mathrm{CgA}$, which was either untreated (light gray bars) or was incubated (at $37^{\circ} \mathrm{C}$ for 60 minutes) with $2 \mu \mathrm{M}$ plasmin, followed by inactivation of the plasmin with $1000 \mathrm{U} / \mathrm{ml}$ Trasylol (dark gray bars). Net percentage of secretion is shown and is calculated as secretagogue-stimulated release minus basal release. Results are mean $\pm \mathrm{SEM} ; n=6$ for each experimental group. ${ }^{A} P<0.01,{ }^{B} P<$ 0.001 compared with nicotine alone. 


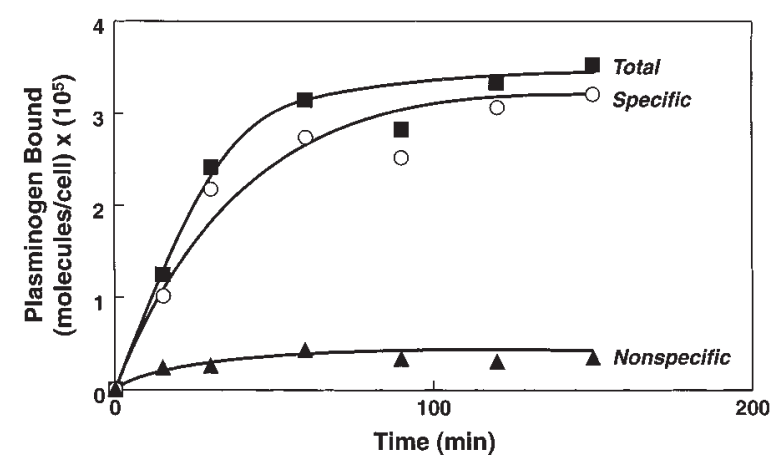

Figure 4

Time course of plasminogen binding to PC12 cells. PC12 cells $(5 \times$ $10^{6} / \mathrm{ml}$ ) were incubated with $0.1 \mu \mathrm{M}^{125}$-plasminogen in the presence of buffer (closed squares) or $10 \mu \mathrm{M}$ unlabeled plasminogen (closed triangles) at $37^{\circ} \mathrm{C}$ for the indicated times. Specific binding (open circles) was calculated by subtracting counts bound in the presence of unlabeled plasminogen from total binding.

(100 nM) was incubated with PC12 cells in suspension, and the time course for the interaction was determined at $37^{\circ} \mathrm{C}$ (Figure 4). Unlabeled plasminogen inhibited the binding of ${ }^{125} \mathrm{I}$-plasminogen by more than $90 \%$, indicating that the interaction was saturable; i.e., there was a discrete number of sites on the cells available to bind plasminogen. Saturable binding was determined by subtracting counts bound in the presence of unlabeled plasminogen (nonspecific binding) from counts bound in the presence of buffer alone (total binding). Apparent binding equilibrium was achieved between 60 and 90 minutes. The interaction exhibited minimal temperature dependence: at a 100-nM input concentration of ${ }^{125} \mathrm{I}$-plasminogen, PC12 cells bound $2.36 \times 10^{5}$ molecules/cell at $4^{\circ} \mathrm{C}$ and $1.38 \times 10^{5}$ molecules $/$ cell at $37^{\circ} \mathrm{C}$.

The interaction was specific for plasminogen: in the presence of the unrelated proteins, lysozyme, ovalbumin, and RNase, less than $4 \%$ inhibition of the interaction of ${ }^{125}$ I-plasminogen with the cells was observed under conditions where an equivalent concentration of unlabeled plasminogen $(5 \mu \mathrm{M})$ gave $68 \%$ inhibition.

Plasminogen binding to most cell types is inhibited by $\omega$-aminocarboxylic acids such as $\varepsilon$-aminocaproic acid (EACA) (38). These compounds interact with the lysinebinding sites in the kringle structures of plasminogen (39). Two hundred millimolar EACA inhibited binding of the ${ }^{125}$ I-plasminogen by more than $98 \%$. To verify that the inhibitory effect of EACA was specific for disruption of lysine-binding site-mediated interactions and not due to other effects, we explored the dose dependence of the inhibition by EACA and also compared the effects of EACA with those of 8-aminooctanoic acid on the interaction. (8-aminooctanoic acid differs from EACA only in the length of its carbon chain and interacts with the lysine-binding sites of plasminogen, also, but interacts with much lower affinity; ref. 40). The inhibition by EACA was concentration dependent, with an $\mathrm{IC}_{50}$ of 98 $\mu \mathrm{M}$ (Figure 5). At a concentration of EACA (0.4 mM) that inhibited ${ }^{125} \mathrm{I}$-plasminogen binding by $72 \%$, less than 5\% inhibition was observed with the same concentration of 8-aminooctanoic acid (Figure 5); 8-aminooctanoic acid inhibited the binding of ${ }^{125} \mathrm{I}$-plasminogen to the cells in a dose-dependent manner also, but with an $\mathrm{IC}_{50}$ of $2.25 \mathrm{mM}$ (Figure 5).

We examined the reversibility of the interaction of plasminogen with the cells. ${ }^{125}$ I-plasminogen was bound to the cells for 60 minutes and then either buffer or EACA was added and incubated for an additional 60 minutes. Seventy-nine percent of the bound ligand was dissociated by the addition of the EACA. When EACA was added simultaneously with the ${ }^{125} \mathrm{I}-$ plasminogen, $93 \%$ of the binding was inhibited. Thus, the interaction was extensively reversible.

Having demonstrated that plasminogen binding was saturable, specific, and reversible, binding isotherms were constructed and gave evidence for saturability (Figure 6a). The data were analyzed in Scatchard plots (Figure 6b). When analyzed using the LIGAND program, the best fit of the data was to a two-site model. The binding parameters for the first site were an apparent $\mathrm{K}_{\mathrm{d}}=77 \mathrm{nM}$ with $4.04 \times 10^{5}$ sites per cell, and for the second site, $K_{d}=8.9 \mu \mathrm{M}$ with $9.8 \times 10^{6}$ sites per cell. The binding isotherm and Scatchard plot corresponding to the first site are shown expanded in the insets in Figure 6 , $a$ and b, respectively.

We also confirmed a published report that the plasminogen-activator t-PA could interact with PC12 cells (27) (Table 1). The t-PA bound to the cells, and the binding was $78 \%$ inhibited by unlabeled t-PA, as well as by arginine and EACA, which also inhibits the binding of t-PA to other cell types (32).

Effect of cells on ${ }^{125} \mathrm{I}$-CgA cleavage. We examined whether cleavage of CgA was enhanced in the presence of cells. PC12 cells were incubated with $2.2 \mu \mathrm{M}$ plasminogen at $37^{\circ} \mathrm{C}$ for 30 minutes to allow plasminogen to bind to the cells. A control incubation was also performed in the presence of 0.1 M EACA, which inhibited plasminogen

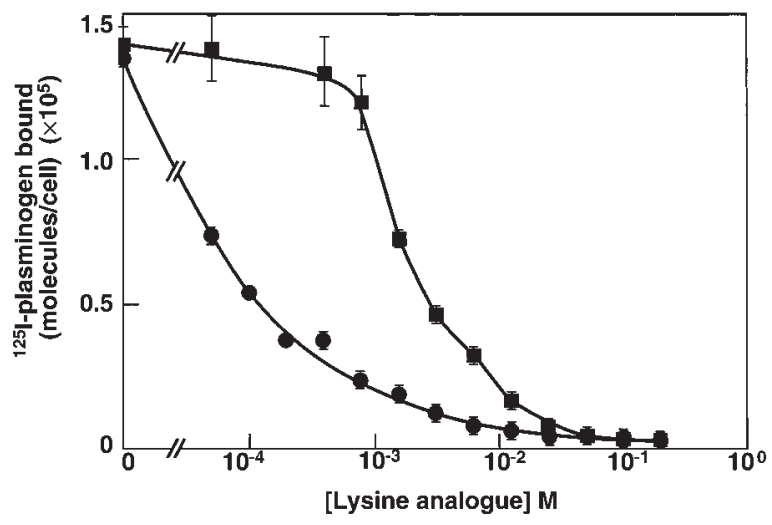

Figure 5

Effect of lysine analogues on plasminogen binding to PC12 cells. PC12 cells $\left(2.5 \times 10^{6} / \mathrm{ml}\right)$ were incubated with $0.1 \mu \mathrm{M}^{125}$ I-plasminogen in the presence of either buffer or increasing concentrations of EACA (circles) or 8-aminooctanoic acid (squares) at $37^{\circ} \mathrm{C}$ for 30 minutes. Total binding is shown. 


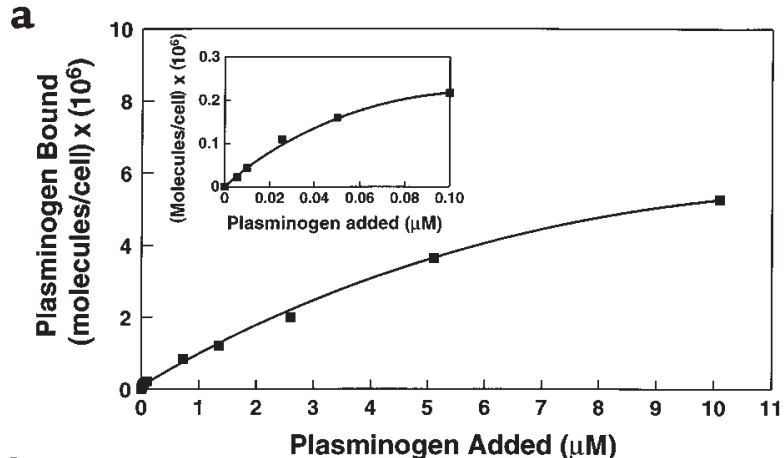

b

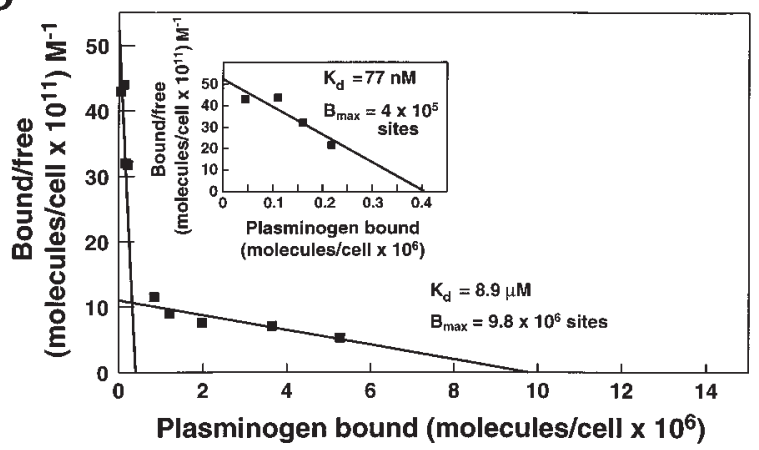

Figure 6

Plasminogen binding to PC12 cells as a function of plasminogen concentration. (a) PC12 cells $\left(10^{7} / \mathrm{ml}\right)$ were incubated with increasing concentrations of ${ }^{125} \mathrm{I}$-plasminogen from $5 \mathrm{nM}$ to $100 \mathrm{nM}$. To measure the lower-affinity binding site, $0.1 \mu \mathrm{M}^{125}$ I-plasminogen was incubated with the cells in the presence of increasing concentrations of unlabeled plasminogen for 1 hour at $37^{\circ} \mathrm{C}$. Nonspecific binding was defined as binding observed in the presence of $0.2 \mathrm{M} \mathrm{EACA}$ and was equivalent to $9.4 \%$ of total ${ }^{125} \mathrm{I}$-plasminogen binding. Specific binding was calculated by subtracting nonspecific binding from total binding. The inset shows the binding isotherm for the high-affinity binding site plotted on an expanded scale. (b) Scatchard analysis of the data obtained in the binding isotherm in a. The inset shows the Scatchard plot for the high-affinity binding site plotted on an expanded scale.

binding by $96 \%$ in this experiment. Then, ${ }^{125} \mathrm{I}-\mathrm{CgA}$ and $3 \mathrm{nM}$ t-PA were added and incubated with the cells. After an additional 30 -minute incubation at $37^{\circ} \mathrm{C}$, the reaction mixtures were added to Trasylol, centrifuged, and the supernatant fluid was analyzed for solubility of ${ }^{125} \mathrm{I}-\mathrm{CgA}$ in $13 \%$ TCA. Results in the presence of cells were compared with controls in the absence of cells. In the presence of cells, the TCA precipitability of ${ }^{125} \mathrm{I}-\mathrm{CgA}$ was significantly decreased, indicative of more extensive CgA processing (to peptides of $M_{r}<6,000$ ), compared with TCA precipitability of ${ }^{125} \mathrm{I}-\mathrm{CgA}$ in the absence of cells (Figure 7). EACA inhibited processing in the presence of cells, but not in the absence of cells. Because EACA inhibits plasminogen binding to the cells, these data are consistent with a significant contribution of cell-associated plasmin to CgA processing.

Effects of modulation of cellular fibrinolytic components on catecholamine release. We examined the effects of both positive and negative modulation of the PC12 fibrinolytic system on catecholamine secretion. First, we performed catecholamine-release experiments in tPA-overexpressing PC12 cells. We compared nicotinemediated catecholamine secretion by the PC12 cell line, \#CS1F9 (a stably transfected cell line that overexpresses t-PA; ref. 35) with control-transfected PC12 cells. The CS1F9 cells have been characterized extensively using t-PA-specific ELISA, immunoblots, protease assay, Northern and Southern blots, with the CS1F9 cells exhibiting approximately fivefold greater t-PA expression than either parent or control-transfected cells (35). The CS1F9 cells and control-transfected PC12 cells were preloaded with $\left[{ }^{3} \mathrm{H}\right]$ norepinephrine. The cells were then stimulated with $60 \mu \mathrm{M}$ nicotine in the presence of $2 \mu \mathrm{M}$ plasminogen. Overexpression of $\mathrm{t}-\mathrm{PA}$ resulted in marked $(81 \pm 2 \%)$ inhibition of stimulated catecholamine release compared with control cells $(P<$ 0.001) (Figure 8). We investigated the effects of plasmin inhibition using a specific anticatalytic antiplasminogen $\mathrm{mAb}$ (see Methods) on the secretion characteristics of these cells. CS1F9 cells were stimulated with $60 \mu \mathrm{M}$ nicotine in the presence of $2 \mu \mathrm{M}$ plasminogen and either an IgG fraction of the anticatalytic antiplasminogen $\mathrm{mAb}$ or normal mouse IgG. In the presence of the anticatalytic antiplasminogen $\mathrm{mAb}$, catecholamine secretion was markedly increased (approximately twofold), compared with the normal mouse IgG control $(P<0.001)$ (Figure 9). Thus, the effect of the antiplasminogen $\mathrm{mAb}$ was to restore nicotine-mediated secretion in these cells. In control experiments, the $\mathrm{mAb}$ had no effect on basal (unstimulated) secretion.

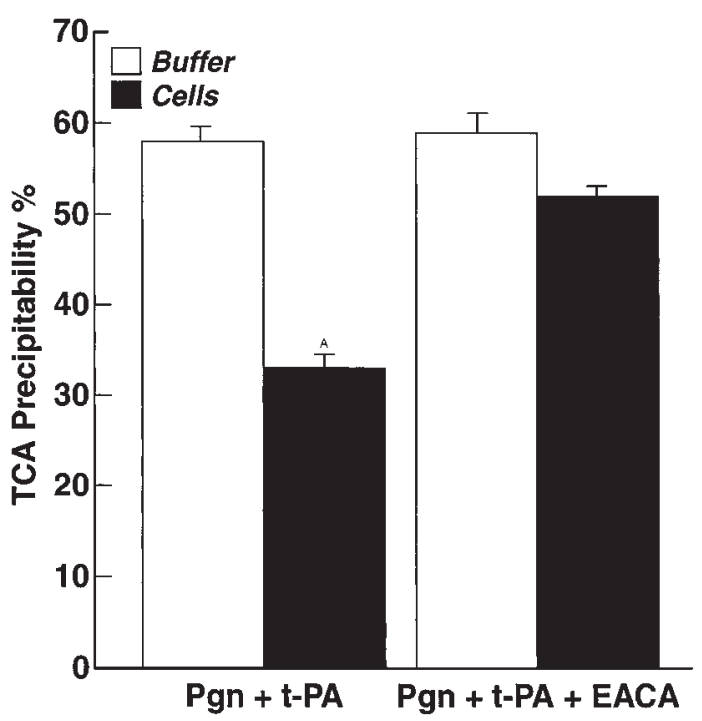

\section{Figure 7}

Effect of cells on cleavage of ${ }^{125} \mathrm{I}-\mathrm{CgA}$ by plasmin. Either PC 12 cells $(1.0$ $\times 10^{7} / \mathrm{ml}$ ) (filled bars) or buffer (open bars) were incubated with 2.2 $\mu \mathrm{M}$ unlabeled plasminogen (pgn) for 30 minutes at $37^{\circ} \mathrm{C}$. Then ${ }^{125} \mathrm{I}-$ $\mathrm{CgA}(50 \mathrm{nM})$ and t-PA $(3 \mathrm{nM})$ were added in either the presence or absence of $0.1 \mathrm{M}$ EACA and further incubated for 30 minutes at $37^{\circ} \mathrm{C}$. The reactions were stopped by addition of $1250 \mathrm{U} / \mathrm{ml}$ Trasylol and centrifuged. The supernatants were analyzed for percentage of TCA precipitability. Results are mean $\pm \mathrm{SEM} ; n=6$ for each experimental group. ${ }^{A} P<0.001$ compared with each of the other experimental groups. 
Table 1

125I-t-PA binding to PC12 cells

$\begin{array}{lcc} & & \text { 125I-t-PA bound } \\ \text { Competitor } & \text { Concentration } & \text { (Molecules/cell) } \times 10^{5} \\ \text { Buffer } & - & 3.6 \\ \text { t-PA } & 15 \mu \mathrm{M} & 1.0 \\ \text { Arginine } & 40 \mathrm{mM} & 2.2 \\ \text { EACA } & 200 \mathrm{mM} & 0.97\end{array}$

DFP-inactivated ${ }^{125} \mathrm{I}$-t-PA at $10 \mathrm{nM}$ was incubated with PC12 cells $\left(7.5 \times 10^{5}\right.$ cells $/ \mathrm{ml}$ ) at $22^{\circ} \mathrm{C}$ for 2 hours in the presence of buffer or the indicated concentration of competitor.

\section{Discussion}

In this study we provide what we believe to be the first evidence that a specific protease system present in the extracellular environment of the chromaffin cell can cleave $\mathrm{CgA}$ into bioactive fragments that inhibit secretagogue-stimulated catecholamine release. Plasmin digestion of $\mathrm{CgA}$ produced peptides that inhibited nicotine-stimulated catecholamine release from both PC12 cells and primary bovine adrenal chromaffin cells. This suggests that the digest contains peptides that may participate in an autocrine negative-feedback mechanism controlling catecholamine release from chromaffin cells that may have important implications in cardiovascular regulation (11). In the presence of $\alpha_{2}$ antiplasmin, the major physiologic inhibitor of plasmin, CgA cleavage into both large and small $\mathrm{M}_{\mathrm{r}}$ products was inhibited, indicating that the cleavage was due to plasmin activity.

As a mechanism for concentrating the activity of plasminogen in the environment into which CgA is secreted, we found that PC12 cells bound plasminogen in a specific, saturable, and reversible manner. Both a highaffinity $\left(\mathrm{K}_{\mathrm{d}}=77 \mathrm{nM}\right)$ and a low-affinity $\left(\mathrm{K}_{\mathrm{d}}=8.87 \mu \mathrm{M}\right)$ interaction of plasminogen with these cells was detected. The identification of a high-affinity plasminogenbinding site on these cells is particularly noteworthy because the $K_{d}$ values measured for plasminogen binding to eukaryotic cells are typically in the $1 \mu \mathrm{M}$ range (24). This high-affinity plasminogen-binding site is predicted to be more than $90 \%$ occupied at plasma and extracellular fluid concentrations of plasminogen (2 $\mu \mathrm{M})$ (19). Rapid processing of CgA occurred at plasmin concentrations corresponding to activation of $1 \%$ and $10 \%$ of circulating plasminogen. Because of the presence of plasminogen-binding sites, the plasminogen concentration in the environment of the chromaffin cell is predicted to be markedly increased, compared with the circulating plasminogen concentration, an effect that would further amplify the cleavage of CgA. Accordingly, we found that in the presence of cells, processing of CgA was enhanced, compared with processing in the presence of buffer. Cell-enhanced cleavage was inhibited in the presence of EACA, a lysine analogue that interferes with plasminogen binding to the cells, implicating plasminogen-binding sites in promoting the enhanced cleavage. We performed these experiments at the physiologic circulating concentration of $\mathrm{CgA}, 1.5 \mathrm{nM}$. The concentration of CgA within the chromaffin vesicle is extremely high, approximately $4 \mathrm{mM}$, so that following exocytosis, the concentration of CgA in the local extracellular space may be as high as $0.4 \mathrm{mM}$ (41). Thus, this increase in substrate concentration also would favor even more rapid processing of $\mathrm{CgA}$ in the environment of the cell after the release reaction. Thus, catecholaminergic cells have the ability to concentrate and spatially organize plasmin activity in the local environment into which CgA is secreted, providing a logical microanatomic and physiologic rationale for a mechanism of local proteolytic processing of $\mathrm{CgA}$.

As a mechanism for further amplification of plasmin formation, binding sites for the plasminogen activators, t-PA (27) and u-PA $(27,42)$, are present on PC12 cells, also. We confirmed the published report that t-PA can also interact with PC12 cells (27). The t-PA binding was saturable because the binding was $78 \%$ inhibitable by unlabeled t-PA. The cells had a high capacity for t-PA. Arginine and EACA also inhibited t-PA binding. Thus, the recognition specificity appears to be similar to t-PA-binding sites described on other cell types (32). t-PA is synthesized by these cells $(21,35,43,44)$ and is coreleased with catecholamines and CgA upon chromaffin cell stimulation $(21,22)$. The released t-PA potentially can bind to its receptors for further amplification of this system.

The importance of the local cellular fibrinolytic system in catecholamine release was tested in experiments using t-PA overexpressing PC12 cells. Overexpression of t-PA resulted in markedly diminished secretagoguestimulated catecholamine release (Figure 8). Conversely, when plasmin activity was inhibited using an anticatalytic $\mathrm{mAb}$, nicotine-stimulated catecholamine

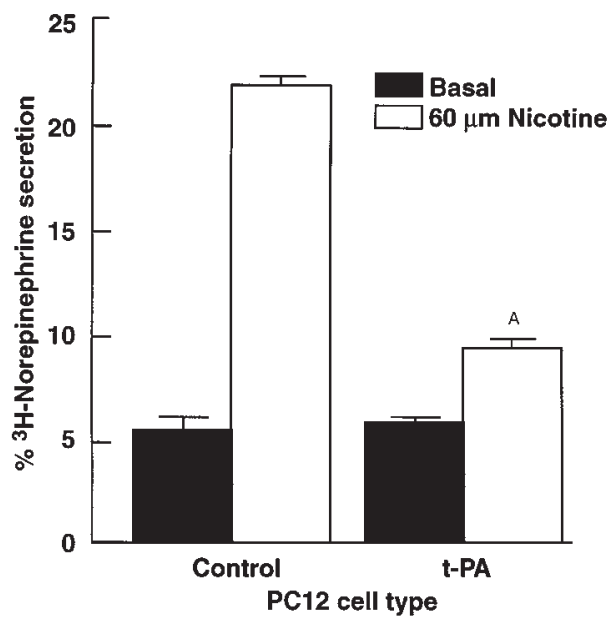

\section{Figure 8}

Decreased nicotine-mediated catecholamine release from PC12 cells overexpressing t-PA. PC12 CS1F9 cells overexpressing t-PA or control-transfected cells were treated with $60 \mu \mathrm{M}$ nicotine (open bars) or buffer (solid bars) in the presence of $2 \mu \mathrm{M}$ plasminogen at $37^{\circ} \mathrm{C}$ for 30 minutes. Results are mean $\pm \mathrm{SEM} ; n=6$ for each experimental group. ${ }^{A} P<0.001$ compared with nicotine-stimulated control cells. 


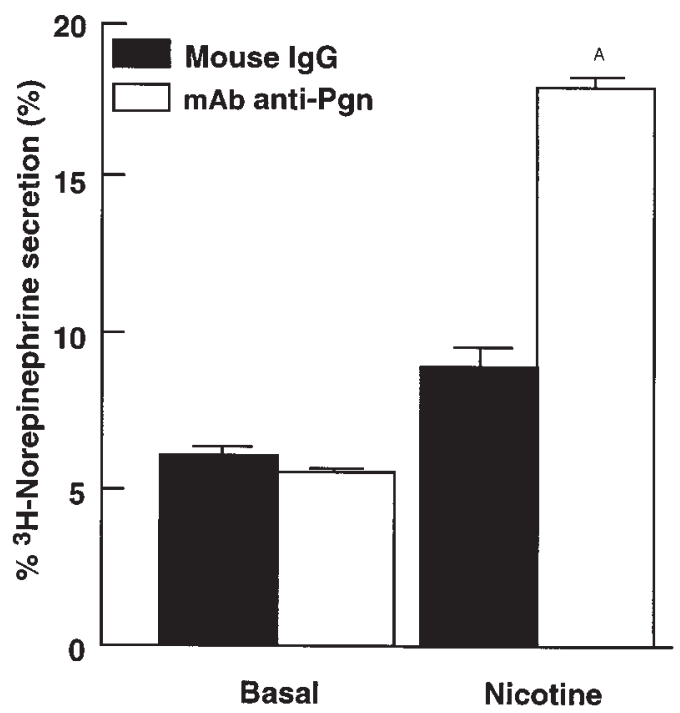

Figure 9

Restoration of catecholamine secretion by anticatalytic antiplasminogen $\mathrm{mAb}$ in PC12 cells overexpressing t-PA. PC12 CS1F9 cells were treated with $60 \mu \mathrm{M}$ nicotine or buffer (basal) in the presence of $2 \mu \mathrm{M}$ plasminogen and $300 \mathrm{nM}$ of either an anticatalytic antiplasminogen mAb (open bars) or normal mouse IgG (closed bars). Results are mean $\pm \mathrm{SEM} ; n=6$ for each experimental group. ${ }^{A} P<0.001$ compared with cells treated with nicotine plus normal mouse IgG.

secretion was substantially increased in these cells (Figure 9). Taken together, these results suggest a major role for fibrinolytic molecules in the regulation of catecholamine secretion. In addition, these results are consistent with the interpretation that overexpression of $\mathrm{t}-$ PA in these cells results in excessive plasminogen activation at the chromaffin cell surface, with a resultant increase in $\mathrm{CgA}$ processing to bioactive peptides that inhibit catecholamine release, an effect that can be reversed by specifically inhibiting plasmin.

Thus, the results of this study demonstrate that (a) the fibrinolytic enzyme plasmin proteolytically cleaves $\mathrm{CgA}$, the major secretory protein of chromaffin cells; (b) proteolysis of $\mathrm{CgA}$ by plasmin is sufficient to liberate bioactive fragments that inhibit secretagogue-stimulated catecholamine release from these cells; (c) augmented activity of the plasminogen/t-PA system by overexpression of $\mathrm{t}-\mathrm{PA}$ leads to decreased catecholamine secretion, and conversely, inhibition of plasmin activity enhances catecholamine release in PC12 cells; (d) plasminogen binds to both a high-affinity $\left(K_{d}=77 \mathrm{nM}\right)$ and to a lower-affinity $\left(\mathrm{K}_{\mathrm{d}}=8.87 \mu \mathrm{M}\right)$ binding site on PC12 pheochromocytoma cells; (e) binding of plasminogen to its cellular receptors on these cells promotes the processing of CgA by plasmin. Expression of plasminogen and t-PA binding sites, taken together with recent results demonstrating expression of t-PA $(21,35,43,44)$ and trafficking of expressed t-PA to catecholamine storage vesicles $(21,22)$, suggest the presence of a local catecholaminergic cell plasminogen/t-PA system that participates in cell-associated neuroendocrine prohormone processing. We present a working model for this system in Figure 10. These interactions between CgA and plasmin(ogen) represent a heretofore unrecognized relationship between catecholaminergic and fibrinolytic pathways and a novel autocrine/paracrine system that may have a dramatic impact upon catecholamine secretion. In addition, $\mathrm{CgA}$ and tPA are expressed together in a variety of neuronal and neuroendocrine tissues (21-23) so that these interactions between $\mathrm{CgA}$ and components of the fibrinolytic system may have broad implications for the processing of CgA and, perhaps, other prohormones throughout the neuroendocrine system. Also, these results demonstrating an interaction between $\mathrm{CgA}$ and plasminogen/t-PA may suggest a new paradigm for prohormone processing in the neuroendocrine system, one consisting of coordinated coexpression, cotrafficking (to the secretory vesicle), and cosecretion of a neuroendocrine prohormone substrate $(\mathrm{CgA})$, along with the activator (t-PA) of the protease system (that is locally concentrated by specific cell-surface binding sites) required for processing in the extracellular space after secretagoguemediated exocytotic secretion.

\section{Acknowledgments}

We thank Randall Pittman for providing the CS1F9 PC12 cell line. This work was supported by the NIH (HL-50398 to R.J. Parmer and HL-38272, HL-45934, and HL-31950 to L.A. Miles) and the Veterans Administration (R.J. Parmer). This work was performed during the tenure of an Established Investigatorship from the American Heart Association (to R.J. Parmer) and during the tenure of an Established Investigatorship from the American Heart Association and SmithKline Beecham (to L.A. Miles).

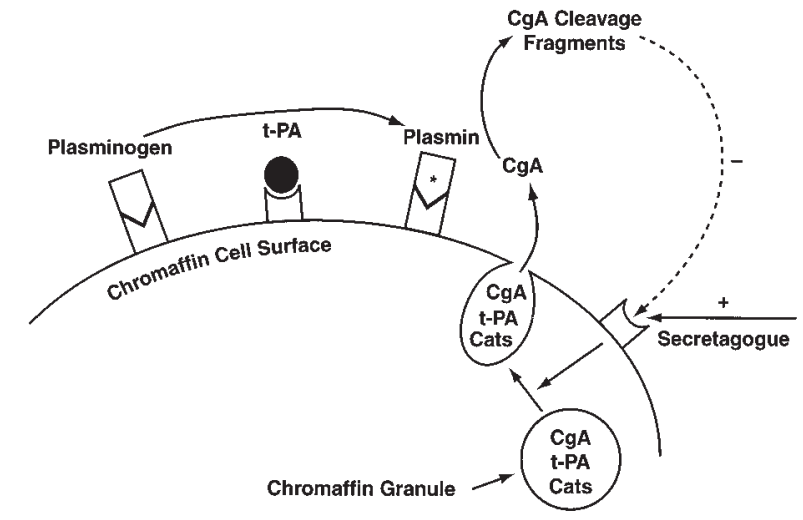

Figure 10

Proposed working model for a local (autocrine/paracrine) chromaffin cell plasminogen/plasmin system and its interactions with CgA. Upon stimulation of the chromaffin cell by a secretagogue, $\mathrm{CgA}$ and catecholamines (Cats) are coreleased by exocytosis. Plasminogen (from circulating sources) and its activator t-PA (synthesized and secreted from the chromaffin cell) bind to the chromaffin cell surface, with resultant activation of plasminogen to plasmin. CgA subsequently is cleaved by plasmin to liberate peptide fragments that provide a negative-feedback loop to modulate subsequent catecholamine release. The asterisk denotes the active enzyme (plasmin). 
1. Winkler, H., and Fischer-Colbrie, R. 1992. The chromogranins A and B: the first 25 years and future perspectives. Neuroscience. 49:497-528.

2. Tatemoto, K., et al. 1986. Pancreastatin, a novel pancreatic peptide that inhibits insulin secretion. Nature. 324:476-478.

3. Aardal, S., and Helle, K.B. 1992. The vasoinhibitory activity of bovine chromogranin A fragment (vasostatin) and its independence of extracellular calcium in isolated segments of human blood vessels. Regul. Pept. 41:9-18.

4. Helle, K.B., et al. 1993. Chromogranin A: secretion of processed products from the stimulated retrogradely perfused bovine adrenal gland. J. Neuroendocrinol. 5:413-420.

5. Hutton, J.C., Davidson, H.W., Grimaldi, K.A., and Peshavaria, M. 1987. Biosynthesis of betagranin in pancreatic beta-cells. Identification of a chromagranin A-like precursor and its parallel processing with proinsulin. Biochem. J. 244:449-456.

6. Drees, B.M., Rouse, J., Johnson, J., and Hamilton, J.W. 1991. Bovine parathyroid glands secrete a 26 -kDa N-terminal fragment of chromogranin A which inhibits parathyroid cell secretion. Endocrinology. 129:3381-3387.

7. Drees, B.M., and Hamilton, J.W. 1994. Processing of chromogranin A by bovine parathyroid secretory granules: production and secretion of $\mathrm{N}$-terminal fragments. Endocrinology. 134:2057-2063.

8. Fasciotta, B.H., Trauss, C.A., Greeley, G.H., and Cohn, D.V. 1993. Parastatin (porcine chromogranin A347-419), a novel chromogranin A-derived peptide, inhibits parathyroid cell secretion. Endocrinology. 133:461-466.

9. Simon, J.-P., Bader, M.-F., and Aunis, D. 1988. Secretion from chromaffin cells is controlled by chromogranin A-derived peptides. Proc. Natl. Acad. Sci. USA. 85:1712-1716.

10. Curry, W.J., et al. 1991. The tissue distribution of rat chromogranin Aderived peptides: evidence for differential tissue processing from sequence specific antisera. Histochemistry. 96:531-538.

11. Mahata, S.K., et al. 1997. Novel autocrine feedback control of catecholamine release. A discrete chromogranin A fragment is a noncompetitive nicotinic cholinergic antagonist. J. Clin. Invest. 100:1623-1633.

12. Metz-Boutigue, M.-H., Garcia-Sablone, P., Hogue-Angeletti, R., and Aunis, D. 1993. Intracellular and extracellular processing of chromogranin A. Determination of cleavage sites. Eur. J. Biochem. 217:247-257.

13. Lindberg, I. 1991. The new eukaryotic precursor processing proteinases. Mol. Endocrinol. 5:1361-1365.

14. Bloomquist, B.T., Eipper, B.A., and Mains, R.E. 1991. Prohormone-converting enzymes: regulation and evaluation of function using antisense RNA. Mol. Endocrinol. 5:2014-2024.

15. Day, R., Schafer, M.K., Watson, S.J., Chretien, M., and Seidah, N.G. 1992 Distribution and regulation of the prohormone convertases PC1 and PC2 in the rat pituitary. Mol. Endocrinol. 6:485-497.

16. Galindo, E., Rill, A., Bader, M., and Aunis, D. 1991. Chromostatin, a 20 amino acid peptide derived from chromogranin A, inhibits chromaffin cell secretion. Proc. Natl. Acad. Sci. USA. 88:1426-1430.

17. Parmer, R.J., et al. 1993. Processing of chromaffin granule proteins: a profusion of proteases? Neurochem. Int. 22:435-444.

18. Weinstein, M.J., and Doolittle, R.F. 1972. Differential specificities of thrombin, plasmin and trypsin with regard to synthetic and natural substrates and inhibitors. Biochim. Biophys. Acta. 258:577-590.

19. Collen, D., and Verstraete, M. 1975. Molecular biology of human plasminogen. II. Metabolism in physiological and some pathophysiological conditions in man. Thromb. Diath. Haemorrh. Suppl. 34:403-408.

20. Vassalli, J.D., Sappino, A.P., and Belin, D. 1991. The plasminogen activator/plasmin system. J. Clin. Invest. 88:1067-1972.

21. Parmer, R.J., et al. 1997. Tissue plasminogen activator (t-PA) is targeted to the regulated secretory pathway: catecholamine storage vesicles as a reservoir for the rapid release of t-PA. J. Biol. Chem. 272:1976-1982.

22. Parmer, R.J., and Miles, L.A. 1998. Targeting of tissue plasminogen activator to the regulated pathway of secretion. Trends Cardiovasc. Med.
8:306-312.

23. Kristensen, P., Hougaard, D.M., Nielsen, L.S., and Dano, K. 1986. Tissuetype plasminogen activator in rat adrenal medulla. Histochemistry. 85:431-436

24. Plow, E.F., Felez, J., and Miles, L.A. 1991. Cellular regulation of fibrinolysis. Thromb. Haemost. 66:32-36.

25. Plow, E.F., Freaney, D.E., Plescia, J., and Miles, L.A. 1986. The plasminogen system and cell surfaces: evidence for plasminogen and urokinase receptors on the same cell type. J. Cell Biol. 103:2411-2420.

26. Hall, S.W., Humphries, J.E., and Gonias, S.L. 1991. Inhibition of cell surface receptor-bound plasmin by $\alpha_{2}$-antiplasmin and $\alpha_{2}$-macroglobulin. $J$. Biol. Chem. 266:12329-12336.

27. Pittman, R.N., Ivins, J.K., and Buettner, H.M. 1989. Neuronal plasminogen activators: cell surface binding sites and involvement in neurite outgrowth. J. Neurosci. 9:4269-4286.

28. Deutsch, D.G., and Mertz, E.T. 1970. Plasminogen: purification from human plasma by affinity chromatography. Science. 170:1995-1996.

29. Wallen, P., and Wiman, B. 1972. Characterization of human plasminogen. II. Separation and partial characterization of different molecular forms of human plasminogen. Biochim. Biophys. Acta. 257:122-134.

30. Syversen, U., Waldum, H.L., and O'Connor, D.T. 1992. Rapid, high-yield isolation of human chromogranin A from chromaffin granules of pheochromocytomas. Neuropeptides. 22:235-240.

31. Miles, L.A., and Plow, E.F. 1985. Binding and activation of plasminogen on the platelet surface. J. Biol. Chem. 260:4303-4311.

32. Felez, J., Chanquia, C.J., Levin, E.G., Miles, L.A., and Plow, E.F. 1991. Binding of tissue plasminogen activator to human monocytes and monocytoid cells. Blood. 78:2318-2327.

33. Greene, L.A., and Tischler, A.S. 1976. Establishment of a noradrenergic clonal cell line of rat adrenal pheochromocytoma cells which respond to nerve growth factor. Proc. Natl. Acad. Sci. USA. 73:2424-2428.

34. Parmer, R.J., Xi, X.-P., Wu, H.-J., Helman, L.J., and Petz, L.N. 1993. Secretory protein traffic. Chromogranin A contains a dominant signal for the regulated pathway. J. Clin. Invest. 92:1042-1054

35. Pittman, R.N., and DiBenedetto, A.J. 1995. PC12 cells overexpressing tissue plasminogen activator regenerate neurites to a greater extent and migrate faster than control cells in complex extracellular matrix. J. Neurochem. 64:566-575.

36. Livett, B.G. 1984. Adrenal medullary chromaffin cells in vitro. Physiol. Rev. 64:1103-1161.

37. Laemmli, U.K. 1970. Cleavage of structural proteins during assembly of the head of bacteriophage T4. Nature. 227:680-685.

38. Miles, L.A., and Plow, E.F. 1988. Plasminogen receptors: ubiquitous sites for cellular regulation of fibrinolysis. Fibrinolysis. 2:61-71

39. Markus, G., De Pasquale, J.L., and Wissler, F.C. 1978. Quantitative determination of the binding of epsilon-aminocaproic acid to native plasminogen. J. Biol. Chem. 253:727-732.

40. Violand, B.N., Byrne, R., and Castellino, F.J. 1978. The effect of alpha-, omega-amino acids on plasminogen structure and activation. J. Biol. Chem. 253:5395-5401.

41. Wightman, R.M. 1995. Kinetics of catecholamine release during exocytosis. 8th International Symposium on Chromaffin Cell Biology. Edinburgh, United Kingdom. S-25:66.

42. Fowler, B.J., Mackman, N., Parmer, R.J., and Miles, L.A. 1996. Molecular basis for the species specificity of single chain urokinase (Scu-PA) binding to the urokinase receptor (u-PAR). Circulation. 94:I512. (Abstr.)

43. Leprince, P., et al. 1991. Modulation of proteolytic activity during neuritogenesis in the PC12 nerve cell: differential control of plasminogen activator and plasminogen activator inhibitor activities by nerve growth factor and dibutyryl-cyclic AMP. J. Neurochem. 57:665-674.

44. Gualandris, A., Jones, T.E., Strickland, S., and Tsirka, S.E. 1996. Membrane depolarization induces calcium-dependent secretion of tissue plasminogen activator. J. Neurol. Sci. 16:2220-2225. 